\title{
Moral Rehabilitation of Juvenile Delinquency in Tamalate District, Makassar City
}

\author{
Syarifuddin \\ University of Muhammadiyah Makassar, Indonesia \\ syarifuddin@unismuh.ac.id
}

\begin{abstract}
Research on the moral rehabilitation of juvenile delinquency in Tamalate sub-district, Makassar city. The purpose of this study (i) to determine the moral rehabilitation process for juvenile delinquency in the Tamalate sub-district, Makassar city. (ii) to determine the effectiveness of juvenile delinquency moral rehabilitation in Tamalate sub-district, Makassar city. The type of this descriptive qualitative research focuses on looking at the social reality of moral rehabilitation for juvenile delinquency. Informants are determined by purposive sampling based on the characteristics of the informants that have been determined. Data collection techniques are observation, interviews, and documentation. The data analysis technique went through several stages, namely data reduction, data presentation and conclusions. The results of this study indicate that, (i) Family, school, and social community have an important role in the moral rehabilitation process for juvenile delinquency in Tamalate sub-district, Makassar city. Various ways are carried out including, more supervision, direction and guidance, and skills. (ii) the effectiveness of moral rehabilitation carried out by the process of supervision, guidance, and skills will be very effective if the three processes run well. Changes in behavior and mindset of adolescents indicate that there is success in rehabilitating, repairing and fostering the behavior of adolescents who deviate.
\end{abstract}

Keywords: Rehabilitation, Morals, Youth

\begin{abstract}
Abstrak. Penelitian tentang rehabilitasi moral kenakalan remaja di kecamatan Tamalate kota Makassar. Tujuan penelitian ini (i) untuk mengetahui proses rehabilitasi moral kenakalan remaja di kecamatan Tamalate kota Makassar. (ii) untuk mengetahui efektifitas rehabilitasi moral kenakalan remaja di kecamatan Tamalate kota Makassar. Jenis penelitian ini kualitatif deskriptif yang berfokus melihat realitas sosial tentang rehabilitasi moral terhadap kenakalan remaja. Informan di tentukan secara purposive sampling berdasarkan karakteristik informan yang telah ditetapkan. Teknik pengumpulan data yaitu observasi, wawancara, dan dokumentasi. Teknik analisis data melalui beberapa tahapan yaitu reduksi data, penyajian data dan kesimpulan. Hasil penelitian ini menunjukkan bahwa, (i) Keluarga, sekolah, dan masyarakat sosial memiliki peran penting dalam proses rehabilitasi moral terhadap kenakalan remaja di kecamatan Tamalate kota Makassar. Berbagai cara yang dilakukan diantaranya yaitu, pengawasan yang lebih, pengarahan dan bimbingan, dan keterampilan. (ii) efektifitas rehabilitasi moral yang dilakukan dengan proses pengawasan, bimbingan, dan keterampilan akan sangat efektif apabila dari ketiga proses tersebut berjalan dengan baik. Perubahan tingkah laku dan pola pikir remaja menunjukkan bahwa terjadi keberhasilan dalam merehabilitasi, memperbaiki dan membina tingkah laku remaja yang melakukan penyimpangan.
\end{abstract}

Kata Kunci: Rehabilitasi, Moral, Remaja 


\section{INTRODUCTION}

An inevitability of development and changing times whose presence cannot be avoided, these changes are marked by the birth of advances in science and technology that always fill the spaces of human life. The presence of technology and information offers a number of facilities and conveniences that can be used in the context of interaction transactions with various components. The more sophisticated communication and information technology will make the process of change in society run quickly. These developments can make it easier for people to obtain as much information as possible through print, electronic media and even the virtual world (internet era). Anyone can access this information from children, teenagers, to adults can easily enjoy the convenience of these facilities.

Teenagers are a very valuable state asset, because they are the successors of the relay for the continuity of leadership in this country. Teenagers as heirs of independence who will continue the development of the previous generation, teenagers have the potential to become future leaders of the nation (Primandha Sukma Nur Wardhani, 2015). Adolescence is part of several phases of human development, in this phase many adolescents experience changes to the next phase, because this phase is a period of transition from childhood to adulthood which includes biological changes, psychological changes, and social changes (Itariyani, 2013). From the transition process, it is very vulnerable to teenagers' behavior outside of the usual, they do this behavior in the context of searching for identity, to find answers to the hidden curiosity within them, so that in the process teenagers sometimes produce a variety of behaviors whether it is good behavior, bad, or attentionseeking behavior to behavior that is not in accordance with the norms prevailing in society, this happens because teenagers do not get supervision and assistance from their families. So that they are free to express their will without prior consideration of the risks that will be caused by their actions, this is because their souls are still unstable. Moreover, there is a lack of supervision from various parties, especially from their parents. This condition occurs because the teenagers' parents are busy with their work, besides that the parents do not know what their children are doing, so there is no effort to supervise the teenagers.

The term moral always refers to the goodness and badness of human actions, not seen from their profession, for example, online motorcycle driver, barbers, lecturers, athletes, artists, but as human beings. The essence of the discussion about morals is that it concerns the area of human life judged by the good and bad deeds as a human being. Moral norms are used as a benchmark to determine the right and wrong of human attitudes and actions, good and bad as humans and not as actors of certain 
limited roles. The moral is very important for everyone, in a nation, so the importance of morals is that some even describe that the size of the good or bad of a nation depends on how moral the nation is. If the nation is morally destroyed, the nation will be destroyed. How important moral is for a society, nation, and people. If morals are damaged, the peace and honor of the nation will also be lost. Therefore, to maintain survival as an honorable nation, it is necessary to pay attention to moral education, both in the family, school and community (Komariah, 2011).

Looking at the dimensions of the development of science and technology, it really provides convenience for mankind, but behind a number of these conveniences it can also have negative implications by eroding the mindset of millennials, especially teenagers. In dealing with situations like this, teenagers often have a slightly more unstable soul and tend to have high sensitivity. Thus many teenagers who fall into things that are contrary to values, morals, religious norms, legal norms, and norms which are prevailing in society. In addition, social norms and religious teachings are explained that the use of substances that can make the wearer drunk is a prohibited act. (Hawi, 2018). Finally, it can be said that teenagers who have unnatural behavior by doing inappropriate actions such as smoking, sucking glue (ngelem), using sedatives and so on, can be categorized as deviant behavior because it is adjacent to the norms that apply in society.

Various behaviors or actions of adolescents that deviate from social norms, these behaviors often cause anxiety and problems for others. These moral deviations can take the form of delinquency or even to the level of crime. Here are some examples of social deviations in adolescents that often occur in society, 1) Rape, this behavior is coercion in the release of male lust for women who become victims. 2) Brawl, this behavior is an act that is often done to a group of teenagers, especially by students who are still in school, this has become news and conversation that is not weird anymore, they think that through violence by way of brawls it is considered a fairly effective problem solver that is carried out by teenagers. 3) Promiscuity, this behavior tends to lead to sex outside of marriage, free sex doesn't seem to be a pervasive thing anymore, it's even become a normal thing. 4) Drug's abuse, this behavior is the abuse and use of illegal drugs, starting because you want to try it, then it becomes a lifestyle until it ends in addiction. 5) Getting drunk, the behavior of drinking liquor until drunk, this behavior is enough to cause unrest in the community because it is not uncommon for this to be a trigger for social conflict, besides that drunken behavior can cause theft in society,

Juvenile delinquency is a social problem and has even become a national problem, 
which of course is the responsibility of all parties to handle and find effective solutions in tackling the behavior committed by these teenagers, one way is to analyze in a comprehensive manner what is the main factor of the juvenile delinquency problem that presence has implications for the decline of adolescent morale, is no exception for teenagers in the Tamalate sub-district, Makassar city. This can be happened if there is participation and intervention from elements in society in order to create a conducive situation to prepare a superior generation towards a great and progressive Indonesia.

By looking at the problem of juvenile delinquency that has occurred recently, it reflects that the lack of understanding and inculcation of moral values or morals of adolescents is a despicable trait and does not reflect good behavior. This deviant behavior should not be carried out by teenagers, especially teenagers who are still in school which in fact are categorized as teenagers who are involved in the world of education. of course this requires special handling to suppress and minimize juvenile delinquency behavior, one of which is by taking preventive and repressive actions through moral rehabilitation which aims to improve and foster the morale of teenagers who are increasingly experiencing degradation (slumps). Social rehabilitation is one form of intervention that can be done to overcome social problems, including juvenile delinquency behavior (Ramadhani et al., 2017). Rehabilitation as a refunctionalization process to enable a person to carry out his social functions properly (Itariyani, 2013). In the context of improving and fostering adolescent morale, this is a shared responsibility between parents, teachers, government and society.

Social Control Theory exists in the civilization of the twenties, eAros (Edward Alsworth Ross), an American sociologist, argues that it is belief systems that guide what people do and that universally control behavior, no matter what form of belief one chooses. (Ross, 2017). One of the Social Control Theory as mentioned by Travis Hirschi in "Social Bond Theory", as follows:

1. Attachments, is the human ability to involve himself with others. The relationship between attachment and deviance is how far the person is sensitive to the thoughts, feelings and wills of others so that he can freely deviate. Attachments are divided into 2 parts, namely: (a) Attachments Total is a condition where an individual releases the feeling that is inside him and replaced with a sense of togetherness. This sense of togetherness encourages a person to always obey the rules, because violating these rules means hurting the feelings of others, (b) Attachments partial is a relationship between one individual and another, where the relationship is not based on the fusion 
of one ego with another ego but because of the presence of other people who supervise. Based on the above, it can be concluded that total attachment will prevent a person's desire to deviate. While partial attachments will only lead to compliance if there are other people who supervise, because if there is no supervision, the person will deviate.

2. Commitment is a person's attachment to conventional sub-systems such as school, work, organization and so on. Commitment is a rational aspect that exists in social bonds. All individual activities such as school, work, activities in the organization will bring benefits to that person. These benefits can be in the form of goods, objects, reputation, future and so on. "All these investments encourage people to obey the applicable regulations, thus these investments can be used as a brake for the desire to deviate.

3. Involvement is a person's activity in the conventional sub-system, if someone is active in an organization then there is little tendency to deviate. The logic of this understanding is that if a person is active in all activities, then that person will spend time and energy in these activities so that he no longer has time to think about things that are against the law. Thus, all activities that can provide benefits will prevent a person from committing acts that are contrary to the law.
4. Beliefs, is a moral aspect which is contained in social ties, Beliefs is a person's belief in existing moral values. One's belief in existing norms will lead to compliance with these norms, which of course will reduce one's desire to violate.

According to Hirschi, these four components must be formed in society, if they fail then the youth will use their rights to violate. To further strengthen this theory, what needs to be done is to cultivate the values of Pancasila and the 1945 Constitution of the Republic of Indonesia as a way of life for citizens who have become the character and identity of Indonesia. So that guiding it is a must for every human who lives in the archipelago.

Labeling Theory, the assumption of this theory is that if someone defines a situation as real, then the consequences will be real (EM Lemert, 2000). FM Lemert distinguishes two forms of deviation, namely:

1. Primary Deviance is a form of first-time violation, tends to be trial and error, unintentional, not serious, childish behavior, trial and error behavior.

2. Secondary Deviance, is a continued violation of self-concept, tends to be reactive, has motivation, is a form of existence, self-fulfilling phropecy. Labeling theory basically emphasizes two, namely:

3. Why and how certain people are labelled. 
4. The influence/effect of the label as a consequence of behavioral deviation.

Labeling theory views that crime is the result of social processes that occur in society, where evil behavior is formed by citizens who have "power", or as a stamp given by the dominant group. This theory is to analyze the labelling, stamp or stigma of drug addicts among teenagers. This labelling has led these teenagers to be more free to express themselves because the stigma that is built up in their minds is whether or not they have been labelled as naughty, or labeled as naughty, finally they are getting more involved in juvenile delinquency which connotes social deviation.

\section{RESEARCH METHODS}

This study uses a descriptive qualitative approach. The sampling technique used in this research is purposive sampling. The data validity techniques are extension of observation, increasing persistence, triangulation, negative case analysis, using reference materials, and conducting member checks. The focus of this research is the process and effectiveness of moral rehabilitation against juvenile delinquency in Tamalate sub-district, Makassar city. The data collection techniques of this research are observation, interviews, and documentation (Manab, 2015). Data analysis through data obtained from data collection techniques, by compiling, editing, classifying and then describing to get conclusions (Sugiyono, 2010). The research data were analyzed through data reduction, namely by reducing the data the researcher tried to combine, classify, classify, sort out or classify data from findings in the field, then the presentation of data (data display) was to present the data, through the presentation of the data, the data will be arranged in a pattern of relationships presented in the form of charts, brief descriptions, written reports that are described (narrative), and finally, verification (conclusion drawing) which is drawing conclusions based on the findings that have been presented in the brief description, where the initially presented conclusions are still temporary, and will change if no strong evidence is found to support the next stage of data collection. The data wetness technique was carried out through source triangulation, time triangulation and technical triangulation.

\section{DISCUSSION}

The problem of juvenile delinquency is an actual problem faced by families, schools, and the community. Circumstances like this have provided a strong impetus to discuss and find out good steps to be taken in order to foster and improve the morale of teenagers who deviate, this is something that is very urgent to address and put special attention on appropriate and efficient ways and actions to be taken to deliver the young generation who have character, are responsible, and behave in 
accordance with the norms prevailing in society. This needs to be done because the current situation seems to give a signal that teenagers' morals are in a slump due to acquaintances of teenagers, where the behavior has increased which makes the public concerned about this condition, ironically again because it seems that the actions that have been taken by law enforcers have not been fully implemented. deterrent effect for teenagers not to re-do deviant behavior in this case juvenile delinquency. This problem is urgent and requires attention from all parties to carry out synergies in minimizing juvenile delinquency behavior which is already at the point of the moral degradation of Tamalate teenagers in Makassar city.

The moral rehabilitation process toward juvenile delinquency is very important, considering the deteriorating morale of teenagers. With the existence of moral rehabilitation, teenagers who commit deviant or juvenile delinquency will be fostered and rehabilitated their morals by educational attitude so that in doing an action, teenagers already understand about the good and bad deeds done in social life. In addition, adolescents are provided with detailed knowledge by exploring information related to deviant behavior that they do is not in accordance with religious teachings and contrary to applicable law, besides providing assistance by instilling legal awareness to adolescents, so that they are always obedient to the laws in force in the Unitary State of the Republic of Indonesia. However, this step can run effectively if all parties can jointly build cooperation and synergize according to their respective roles to take action against juvenile delinquency behavior.

The family environment, school, and society, in general, have a very important role in the moral rehabilitation process for juvenile delinquency in Tamalate sub-district, Makassar city. Where the environment has the most potential to be a trigger for juvenile delinquency, because teenagers make the environment a habitat, a place to hang out, and space for interaction transactions to exchange information. Various ways are done including by carrying out extra supervision (controlling), and providing direction (guidance), and involving them in skill activities with the aim of keeping them busy with a number of positive activities so that teenagers will no longer do things that are contrary to their moral values and norms prevailing in society

In the process of providing extra supervision to adolescents showing significant progress, it is seen that there have been visible changes in adolescents, one of which is changes in adolescent behavior, mindset, and others. Controlling children's behavior cannot be separated from the cooperation between teachers and parents, as teachers control all behavior and activities that occur in the school environment such as academic issues, character building, and others. But apart from 
that, parents are also in charge of controlling the behavior and activities of children in the family and surrounding environment. Controlling the child's association, where and with whom he hangs out, supervises all activities of the child both at home and in the community. Parents build good communication with teachers to always know about children's behavior at school, so they can anticipate if there are unwanted things are likely to be done by children in the school environment.

Guiding and directing teenagers slowly changing their mindset so that they behave well and always think positively by using a religious approach, providing maximum education in order to instill the importance of learning and practicing moral values and norms that apply in society. So that adolescents understand the impact of each action that will be done. It can be seen that with the guidance carried out, there is a sense of fear and a deterrent effect on teenagers not to repeat their mistakes because they already know that every action they take must have an impact, both positive and negative. There are many considerations to think about if there is an intention to deviate again. Directing or guiding from parents, teachers, and the surrounding community can result awareness in the youth themselves so that an attitude of self-control is embedded in them in socializing together with their friends. This self-control attitude also leads them to become teenagers who have good personalities in each of their activities.

Positive activities in the community are one of the steps and processes to prevent adolescents from committing social deviations with the consideration that if they are active adolescents in these activities, they are likely to focus more on thinking about these activities. So that there is no time to think about things that are against the norms prevailing in society because their minds are focused on the positive activities they are doing. The ability to use reason, thoughts, ideas, and creativity in doing something, by making something more meaningful so as to produce value for the benefit of the work. Thus, adolescents can fill their spare time with more useful activities, as well as being able to channel and develop their talents. In addition, teenagers are also involved in social activities such as social services, mutual cooperation, and other community activities, of course, the goal is to keep them busy so that there is no more room for them to commit deviant behavior.

Everything that is done starting from supervision, directing (guidance), and skills to adolescents is an effective process carried out because there have been significant changes in adolescents, both changes in mindset and behavior of adolescents. This is shown in the reduction of juvenile delinquency such as brawls, drugs abuse, illegal racing, and so on related to juvenile delinquency. The rest that 
needs to be considered is to continue to oversee these steps so that there is a continuous consistency in order to prevent and minimize the occurrence of delinquency in adolescents so that what has been done can be applied continuously. The effectiveness of moral rehabilitation carried out with the process of supervision, guidance, and skills will be very effective if all these processes run well. Changes in behavior and mindset of adolescents indicate that there is a level of success obtained. This achievement becomes an indicator and benchmark for the success of a program that has been designed to achieve a goal. Likewise with moral rehabilitation in adolescents who commit juvenile delinquency by behaving deviantly, records show progress and improvement in changes in attitudes and behavior of adolescents significantly, Behavior change for the better is certainly the target and goal of the adolescent's moral rehabilitation. Thus it can be concluded that these steps and processes are considered successful in improving and fostering the behavior of adolescents who commit social deviations, turning into teenagers who are able to behave well in living the social life, nation, and state.

\section{CONCLUSION}

The moral rehabilitation of juvenile delinquency in Tamalate sub-district of Makassar City went through several processes, namely controlling, directing, guiding, providing skills which were carried out both from the family, school, and community. As parents, as well as educators, should always provide supervision to adolescents or students so that they do not fall into deviant associations. Moral rehabilitation carried out through a process of supervision, guidance, and skills will run effectively if the process can synergize with all parties so that it can run continuously. In addition, there must be directing or providing understanding to teenagers that such things will harm themselves and others. To reduce the level of juvenile delinquency, there must be social sanctions given with the aim of creating a deterrent effect on adolescents. If it is already running then we must provide space for students or youth so that they are able to practice their abilities in the fields of interest through programs that have been designed. Moral rehabilitation can be carried out effectively if all components can synergize properly, carrying out their social roles and functions professionally in overseeing the process, the most important things that must be considered to realize it is as supervision, guidance, and providing skills to adolescents, this has a very effective role by seriously carrying out the rehabilitation process carefully, then there is a great chance that it will run well. Changes in behavior and mindset of adolescents indicate that there is a level of success obtained, in the sense that it has succeeded in improving and fostering the 
behavior of adolescents who deviate. However, to be more optimal and to remain consistent in changing the behavior and mindset of these teenagers, continuous supervision and control are needed and so that teenagers do not commit deviant behavior in the future for the sake of creating a superior generation towards great Indonesia.

\section{REFERENCES}

[1] Hawi, A. (2018). Adolescent Drug Addicts: A Study on Integrative Rehabilitation at the Narcotics Rehabilitation Center, Pondok Pesantren Ar-Rahman Palembang. Tadrib: Journal of Islamic Religious Education, 4(1), 99-119.

https://doi.org/10.19109/tadrib.v4i1.1958

[2] Hasnah, K. (2020). PENGUATAN PENDIDIKAN KARAKTER: BERBASIS INTEGRATIF MORAL DI PERGURUAN TINGGI (Vol. 1). CV. AA. RIZKY.

[3] Itariyani, N. (2013). Moral Development for School Dropout Teens at the "Wira Adhi Karya" Social Rehabilitation Center Ungaran. SEMARANG STATE UNIVERSITY.

[4] Komariah, KS (2011). Moral Values Education Model for Teenagers According to the Islamic Perspective. Journal of Islamic Religious Education-Ta'lim, 9(1), 45-54. https://scholar.google.com/scholar?hl=id\&as _sdt $=0 \% 2$ C5\&q=komariah $+2011+$ value + mo ral\&oq=Komariah+\%282011\%29

[5] Kanji, H., Nursalam, N., Nawir, M., \& Suardi, S. (2020). Integration of social care characters and moral integratif on social science lessons in elementary school. Al-ishlah: Jurnal Pendidikan, 12(2), 413-427.

[6] Lemert, EM (2000). Crime and Deviance (CC Lemert \& MWF (eds.)). United States of America.

https://books.google.co.id/books?hl=id\&lr= \&id=yPCDLAuXZ14C\&oi=fnd\&pg $=$ PP11\& $\mathrm{dq}=$ edwin+lemert+labelling+theory\&ots $=\mathrm{TT}$ Dc2gbn6a\&sig=TpHA0m2jlz9sGa8Zonecpa ge\&qre\#f=fonecpage $=\mathrm{TTDc} 2 \mathrm{gbn} 6 \mathrm{a} \& \mathrm{sig}=$
[7] Manab, A. (2015). Educational Research, Qualitative Approach (K. Aibak (ed.); 1st ed.). CALIMEDIA. http://repo.iaintulungagung.ac.id/10156/1/Qualitative Approach Educational Research.pdf

[8] Mardiana, M., Syahrir, M., \& Nurmutmainnah, N. (2021). The Influence of Pancasila and Citizenship Education Teachers in Instilling Moral Ethics to Build National Character in Madrasah Aliyah Syekh Yusuf Sungguminasa. JED (Journal of Etika Demokrasi), 6(1), 124-137.

[9] Nur, R., \& Kanji, H. (2021). Integrated Model of Character Education Development Based on Moral Integrative to Prevent Character Value Breaches. AL-ISHLAH: Jurnal Pendidikan, 13(1), 107-116.

[10] Nur, R., Suardi, S., Nursalam, N., \& Kanji, H. (2021). The Integration Model of the Development of Student Religious Character Education Based on Integrative Morals in Higher Education. JED (Journal of Etika Demokrasi), 6(1), 149-162.

[11] Nursalam, S. S. (2016). Teori Sosiologi Klasik, Modern, Posmodern, Saintifik, Hermeneutik, Kritis, Evaluatif, dan Integratif. Yogyakarta: Writing Revolution.

[12] Primandha Sukma Nur Wardhani. (2015). Moral Development of Dissocial Youth at the Semarang II Independent Social Rehabilitation Center, Semarang City. In UNNES. SEMARANG STATE UNIVERSITY.

[13] Ramadhani, WS, Sulasti, S., \& Nurhaqim, HSA (2017). The Process of Social Rehabilitation of Prostituted Women at the Palimanan Women's Social Rehabilitation Center (Brskw) Cirebon Regency. Proceedings of Research and Community Service, 4(2), 241-245. https://doi.org/10.24198/jppm.v4i2.14292

[14] Ross, EA (2017). Social Control A Survey of The Foundations of Order. In Social Control (pp. 1-449). Routlede. https://books.google.co.id/books?hl=id\&lr= \&id=UTgrDwAAQBAJ\&oi=fnd\&pg=PR $2 \&$ $\mathrm{dq}=$ edward+alsworth+ross+social+control\& ots=h0biVay1yQ\&sig=NzJ3irLhrd$8 \mathrm{~K} 5 \mathrm{CoU} 7=\& \mathrm{req} 4 \mathrm{mS} 95=$ truec $\&$ req 
[15] Sugiyono. (2010). Qualitative Quantitative Research Methods and R \& D. In Alphabeta (10th ed.). https://www.pdfdrive.com/prof-drsugiyono-method-penelitian-kuantitatifkualitatif-dan-rd-intro-d56379944.html

[16] Suardi, S. (2018). Penerapan Model Pembelajaran Saintifik Approacd Berbasis Media Pembelajaran Kearifan Lokal pada Mata Kuliah Dasar-Dasar Sosiologi dalam Membangun Karakter dan Meningkatkan Hasil Belajar Mahasiswa Pendidikan Sosiologi Universitas Muhammadiyah Makassar. JED (Journal of Etika Demokrasi), 3(2). 